\title{
RESEARCH PAPER \\ The effect of foliar applications of a bio-stimulant derived from algae extract on the physiological behavior of lulo seedlings (Solanum quitoense cv. Septentrionale)
}

\author{
Jhon J. Díaz-Leguizamón, Oscar F. Chingaté-Cruz, Alefsi D. Sánchez- \\ Reinoso, and Hermann Restrepo-Díaz \\ Departamento de Agronomía, Facultad de Ciencias Agrarias, Universidad Nacional de Colombia. Carrera \\ 30 No 45-03, Bogotá D.C., Colombia.
}

\begin{abstract}
J.J. Díaz-Leguizamón, O.F. Chingaté-Cruz, A.D. Sánchez-Reinoso, H. Restrepo-Díaz. 2016. The effect of foliar applications of a bio-stimulant derived from algae extract on the physiological behavior of lulo seedlings (Solanum quitoense cv. Septentrionale). Cien. Inv. Agr. 43(1):25-37. Seaweed extracts are used as nutritional supplements, biostimulants, or biofertilizers in agriculture and horticulture to increase plant growth and yield. In this experiment, foliar applications of bio-stimulant derivate from seaweed extract were tested on plant growth, leaf gas exchange properties, and proline accumulation in lulo seedlings cultivated under greenhouse conditions. Lulo plants were split into four treatments: (i) plants with soil fertilizer; (ii) plants treated only with foliar bio-stimulant sprays; (iii) a combination of soil fertilizer plus a foliar bio-stimulant application; and (iv) a control treatment (without nutrient application). Lulo plants treated with soil fertilizer and foliar bio-stimulants increased growth, as this group of plants showed a higher total plant dry weight, stem diameters, and absolute growth rate. Lulo plants without soil fertilizater and treated with foliar bio-stimulant application had lower leaf gas exchange (photosynthesis, stomatal conductance, and plant transpiration) and leaf chlorophyll content. Foliar biostimulant sprays enhanced the partitioning of dry mass in floral cushions. In conclusion, the application of foliar bio-stimulant applications as a complement to soil fertilizer is a technique that can be employed in the cultivation of lulo because foliar sprays of these kinds of agrochemicals can enhance dry matter accumulation and blooming.
\end{abstract}

Key words: Foliar sprays, growth rates, proline, PSII efficiency, soil fertilizer

\section{Introduction}

Lulo (Solanum quintoense L.) is a native fruit species from the rain forests of the South American Andes and is mainly found in countries such as

Received August 10, 2015. Accepted February 26, 2016. Corresponding author: hrestrepod@unal.edu.co
Colombia, Ecuador and Peru. In Colombia, the production of this fruit for the year 2013 was 68,748 tons in a total of 7,327 hectares (Agronet, 2015).

The plant yield is especially influenced by fertilization supplied during its growth and development (Mengel et al., 2001). Additionally, soil fertilization is the principal method by which crops are 
provided with essential nutrients (Maschnner, 2012). Moreover, crop plants can uptake nutrients and/or other growth-promoting substances (hormones, carbohydrates, and amino acids) through leaves under appropriate concentrations (Fageria et al., 2009). Consequently, the foliar application of fertilizers and bio-stimulants is a complementary technique that can: (i) promote growth (Ardebili et al., 2012); (ii) increase crop production (Fageria et al., 2009); and/or (iii) reduce the negative effects caused by abiotic stress conditions in specific periods during crop development (Calvo et al., 2014).

Generally, it has been reported that the use of substances such as amino acids, vegetable extracts, and/or bio-stimulants have shown positive effects on plant growth and yield (Brown and Saa, 2015). Applications of plant biostimulants have enhanced growth, yield and fruit quality in tomatoes (Zodape et al., 2011; Hernández-Herrera et al., 2014), increased net photosynthesis, transpiration rate, and the intercellular concentration of $\mathrm{CO}_{2}$ in maize (Anjum et al., 2011), and triggered early flowering and fruit set in a number of crop plants (Khan et al., 2009).

Measurements of free amino acid contents (alanine, asparagine, or proline) may reflect changes in the nutrition conditions of these plants (Al-Karaki et al., 1996). In this regard, the accumulation of free proline in plants is an indicator of the degree of acclimation to abiotic stress conditions (Claussen et al., 2006). Furthermore, the determination of proline has also been used as an indicator of plant responses to mineral nutrition treatments (Neuberg et al., 2010). Al-Karaki et al. (1996) found that sorghum leaves showed an increased proline accumulation when supplied with a higher level of phosphorus. Additionally, an increase of this free amino acid was observed in tomato and pepper plants under conditions of boron toxicity (Eraslan et al., 2007).
In contrast, the collection of growth rates allows a quantitative approach to understand the growth of a plant or a population of plants under different cropping practices such as the fertilizer application method or the effect of fertilizers (Gil and Miranda, 2007). Growth rates such as the absolute growth rate, relative growth rate (RGR) and/or the leaf weight ratio (LWR) have been used to model the effectiveness of the fertilization treatments (Neuberg et al., 2010).

In general, the studies that have been developed in lulo crops ( $S$. quintoense) in Colombia have been focused mainly on the areas of post-harvest, plant pathology, and agro-industrial processing (Medina et al., 2009). However, studies on the physiological behavior of this species with regards to mineral nutrition have been poorly documented. Additionally, the studies on the response to foliar fertilization using biostimulants or amino acids, as well as reports on the agronomic performance of the use of these products in horticultural crops in tropical areas, especially $S$. quitoense, are scarce because the available literature is mainly geared towards understanding the response of lulo plants to the effect of foliar nitrogen applications (Parra-Coronado et al., 2015; Florez-Velasco et al., 2015). Consequently, these kinds of studies with biostimulants derived from seaweeds and/or amino acids become highly valuable because they have an important influence on crop productivity. Additionally, data on the effects of plant biostimulant use on proline accumulation in leaves of this species is not available in terms of abiotic stress effects such as, in this case, nutritional deficiencies. Therefore, the objective of this study was to evaluate the effect of foliar application of a biostimulant derived from seaweed as a supplement of the soil fertilization in lulo plants (S. quitoense cv. Septentrionale) on physiological processes such as photosynthesis, stomatal conductance, transpiration, growth rates, and biochemical processes such as proline production. 


\section{Materials and methods}

\section{Plant material and growth conditions}

The present work was conducted in the unheated greenhouses of the Faculty of Agrarian Sciences of the Universidad Nacional de Colombia, Bogotá (latitude $4^{\circ} 35^{\prime} 5^{\prime \prime}$ "north and longitude $74^{\circ} 04^{\prime}$ '51" west) for 150 days. Sixty-day-old lulo seedlings cv. Septentrionale were transplanted into 4-L plastic pots containing a peat-sand mixture (in a 2:1 relationship (v/v)) as a substrate. In addition, the space between pots was $25 \mathrm{~cm}$. In general, the experiment area used was approximately $8 \mathrm{~m}^{2}$ in the greenhouse. Finally, the growing conditions in the unheated greenhouse during the test were an average temperature of $22^{\circ} \mathrm{C}$, a relative humidity $60 \%$ to $90 \%$, and a natural photoperiod of $12 \mathrm{~h}$.

\section{Treatments}

Lulo seedlings had an acclimation period of 15 days after transplanting (DAT) during which time they were irrigated weekly with $400 \mathrm{~mL}$ of distilled water throughout the experiment. After this period of acclimation, plants were subjected to four different nutrition treatments. Fertilizer treatments consisted of: (i) a group of plants with soil fertilizer; (ii) plants treated only with a bio-stimulant through foliar sprays; (iii) a combination of soil fertilizer plus a foliar bio-stimulant application; and (iv) a control treatment (without nutrient application). The soil fertilization consisted in supplying a 1515-15 compound fertilizer (TRIAN 15® Yara, Colombia) as a source of nitrogen, phosphorus, and potassium at a dose of $5 \mathrm{~g}$ per plant. In addition, a compound fertilizer with microelements at a dose of $1 \mathrm{~g}$ per plant (Agrimins, Colinagro ${ }^{\circledR}$, Colombia) was added. The Agrimins composition was $8 \%$ total nitrogen ( $1 \%$ ammonia $\mathrm{N}$ and $7 \%$ urea $\mathrm{N}$ ), $5.0 \%$ assimilable phosphorus $\left(\mathrm{P}_{2} \mathrm{O}_{5}\right), 18 \%$ calcium $(\mathrm{CAO}), 6 \%$ magnesium ( $\mathrm{MgO}), 1.6 \%$ total sulfur, $1 \%$ boron, $0.75 \%$ copper, $0.005 \%$ molybdenum, and $2.5 \%$ zinc. Soil fertilizer was applied at 0,34 , and 75 DAT. For the foliar application treatments, a bio-stimulant derived from algae (Ascophyllum nodosum) was used (Masai ${ }^{\circledR}$, Colinagro, Colombia) at a dose of $3 \mathrm{~mL} \mathrm{~L}^{-1} \mathrm{H}_{2} \mathrm{O}$. The bio-stimulant had a concentration of $139 \mathrm{~g}$ of organic carbon per liter of nutrient solution. Seven foliar applications were made at 22, 44, 66, 88, 110, 132, and 147 (DAT), respectively. Foliar applications were carried out between 8:00 a.m. and 10:00 a.m. using a handheld sprayer (Garden, Royal Condor $^{\circledR}$, Colombia) on both the surface and the underside of leaves. The foliar sprays were carried out during those day hours to guarantee a higher contact of solution with the leaf surface. Likewise, the spray volume applied per plant during biostimulant application was 100 $\mathrm{mL}$. Lulo seedlings were sprayed until solution ran off the leaves, but pots were covered with plastic to prevent excess run-off from entering the substrate. For the treatment in which soil fertilizer plus foliar bio-stimulant was applied, a method combining the two techniques described in the two previous treatments (soil fertilization and foliar application of bio-stimulant) was performed.

Dry weight, leaf area, specific leaf area, stem diameter, and shoot length

Total dry plant weight (TDPW), leaf area, and shoot length were determined at 36, 59, 97, and 150 DAT. TDPW was obtained by harvesting six plants per treatment at each sampling date. Then, plants were dried in a compressed dry air oven (Mod 27 Thelco, Chicago, USA) at $80{ }^{\circ} \mathrm{C}$ for $48 \mathrm{~h}$ in order to obtain dry weight. Leaf area was also recorded from the plants harvested in TPDW using a leaf area meter (Li3100, LiCorinstruments, Nebraska, USA). At the end of the experiment (150 DAT), the specific leaf area was calculated by the ratio of the leaf area and leaf dry weight $\left(\mathrm{cm}^{2} \mathrm{~g}^{-1}\right)$. The stem diameter was also determined at 150 DAT, and it was taken in the stem segment that was located $8 \mathrm{~cm}$ above the substrate surface. 


\section{Growth components}

To determine the growth components, absolute growth rate (AGR), relative growth rate (RGR), and net assimilation rate (NAR) were determined at $36,59,97$, and 150 DAT using the following equations described by Carranza et al. (2009):
a)
$A G R=\left(\frac{d W}{d t}\right) ; m g d^{-1}$
b)
$R G R=\left(\frac{1}{W}\right)\left(\frac{d W}{d t}\right) ; m g g^{-1} d^{-1}$
c)

$$
N A R=\left(\frac{1}{L_{A}}\right)\left(\frac{d W}{d t}\right) ; \mu g \mathrm{~cm}^{-2} d^{-1}
$$

$\mathrm{W}=$ total dry weight $(\mathrm{g}) ; \mathrm{L}_{\mathrm{A}}=$ leaf area $\left(\mathrm{cm}^{2}\right)$; $\mathrm{dW}=$ dry weight $(\mathrm{mg}$ or $\mu \mathrm{g})$; and $\mathrm{dt}=$ time $(\mathrm{d})$.

\section{Leaf chlorophyll content (SPAD units)}

Three readings were conducted on a fully extended leaf from the upper middle portion of canopy using a SPAD chlorophyll meter (SPAD502, Konica Minolta Sensing, Inc., Ramsey, NJ, USA). In general, two mature leaves were used to determine the chlorophyll content per replicate. Leaf SPAD readings were estimated at 97 and 145 DAT. Finally, the SPAD value represents the mean of six readings.

\section{Photosynthesis and stomatal conductance}

Photosynthesis $\left(\mathrm{P}_{\mathrm{n}}\right)$ and stomatal conductance $\left(g_{\mathrm{s}}\right)$ of leaves were estimated using a portable photosynthesis system (Li-Cor 6200, Lincoln, Nebraska, USA) and a porometer (SC-1, DecagonDevices, Pullman WA, USA) between 145 and 150 DAT, respectively. $\mathrm{P}_{\mathrm{n}}$ and $g_{\mathrm{s}}$ measurements were determined in fully expanded leaves from the upper middle part of the plant. $\mathrm{P}_{\mathrm{n}}$ and $g_{\mathrm{s}}$ data come from a group of measurements taken for 5 days, between 10:00 a.m. and 4:00 p.m.

\section{Photosystem II Efficiency $\left(F_{v} / F_{m}\right)$}

To determine the efficiency of photo system II ( $\mathrm{F}_{\mathrm{v}} /$ $\mathrm{F}_{\mathrm{m}}$ ), a continuous excitation fluorometer (Handy PEA, Hansatech Instruments, Kings Lynn, UK) was used at 145 DAT. Two full-grown leaves (the same leaves used to determine photosynthesis) were used to determine the $\mathrm{F}_{\mathrm{v}} / \mathrm{F}_{\mathrm{m}}$ ratio by using clips in order to ensure the acclimation of a portion of leaf in total darkness for $10 \mathrm{~min}$.

\section{Transpiration and Water Use Efficiency}

Total plant transpiration was estimated on the same dates of $\mathrm{P}_{n}$ and $\mathrm{g}_{\mathrm{s}}$ using the gravimetric technique described by Florez-Velasco et al. (2015), which consists of measuring the difference in the weight of the plants in their pots every $24 \mathrm{~h}$. Water use efficiency (WUE) was determined using the Raviv and Blom (2001) method, which consists of obtaining the ratio of the total dry weight of the plant versus the total amount of water that each plant received throughout the experiment.

\section{Proline content}

Proline determinations were made at 148 DAT by collecting approximately $1 \mathrm{~g}$ of fresh leaf tissue. The plant material was then processed with liquid nitrogen in order to preserve the plant tissue until analysis. Based on the method described by Bates and Waldren (1973), a sample of $0.3 \mathrm{~g}$ of tissue was homogenized in $10 \mathrm{~mL}$ of $3 \%$ aqueous solution of sulfosalicylic acid (Merck Millipore, Darmstadt, Germany). Then, this preparation was filtered through a Whatman \#2 filter paper. Two milliliters of the filtered substance were then reacted with $2 \mathrm{~mL}$ of ninhydrin acid (Panreac, Castellar del Valles, Spain) and $2 \mathrm{~mL}$ of glacial acetic acid (J.T. Baker, Mexico, Mexico). This mixture was placed in a water bath (B-480, Buchi, Postfach, Switzerland) for one hour at 90 
${ }^{\circ} \mathrm{C}$, and the reaction was quenched with dry ice. Then, the reaction mixture was extracted with $4 \mathrm{~mL}$ of toluene (J.T. Baker, Mexico, Mexico), agitating the test tubes vigorously with a vortex mixer. The absorbance was measured at $520 \mathrm{~nm}$ using a spectrophotometer (SpectronicBioMate 3 UV - Vis, Thermo, Madison, WI, USA). The proline content was determined using a standard curve, and it was calculated on fresh weight basis with the following equation in the entire experiment: $[(\mu \mathrm{g}$ proline $/ \mathrm{mL} \times \mathrm{mL}$ toluene $) / 115.5 \mu \mathrm{g}$ $\mu$ moles $\left.^{-1}\right] /[($ g sample $) / 5]=\mu$ moles proline $/ g$ fresh weight of the material.

\section{Experimental design and statistical analysis}

A completely random design was used in order to analyze data. Six plants were randomly sampled for each treatment at each sampled point. A total of twenty four plants per treatment were used for four measurements in the whole experiment. When significant differences were found, the test for comparison of treatment means was performed using the Tukey test. Data were analyzed using the program Statistix v 8.0 (analytical software, Tallahassee, FL, US).

\section{Results}

Accumulation of dry matter, shoot length, leaf area and distribution of assimilates

Results of the accumulation of dry matter and total shoot length in lulo seedlings subjected to different fertilization treatments are presented in Figure 1 (A and B, respectively). Figure 1A shows that significant differences were found between treatments at 97 and 150 DAT. Lulo plants under the treatment of soil fertilizer and soil + foliar bio-stimulant sprays had a greater accumulation of dry matter at the end of the experiment. At 150 DAT, the greatest biomass accumulation occurred in plants treated with soil fertilizer + foliar bio-stimulant applications, with an increase of $\sim 240 \%$ compared to the treatment without nutrient applications (control treatment). In plants treated only with soil fertilizer dry matter increased approximately $\sim 140 \%$ with respect to the control treatment. Plants with foliar bio-stimulant applications showed no significant changes in dry matter accumulation compared to plants without fertilizer applications throughout the experiment (Total Plant Dry weight in both treatment did not exceed $20 \mathrm{~g}$ at the end of the study). Finally, shoot length was higher in lulo plants treated with soil fertilizer and soil fertilizer + foliar bio-stimulant (Figure 1B).

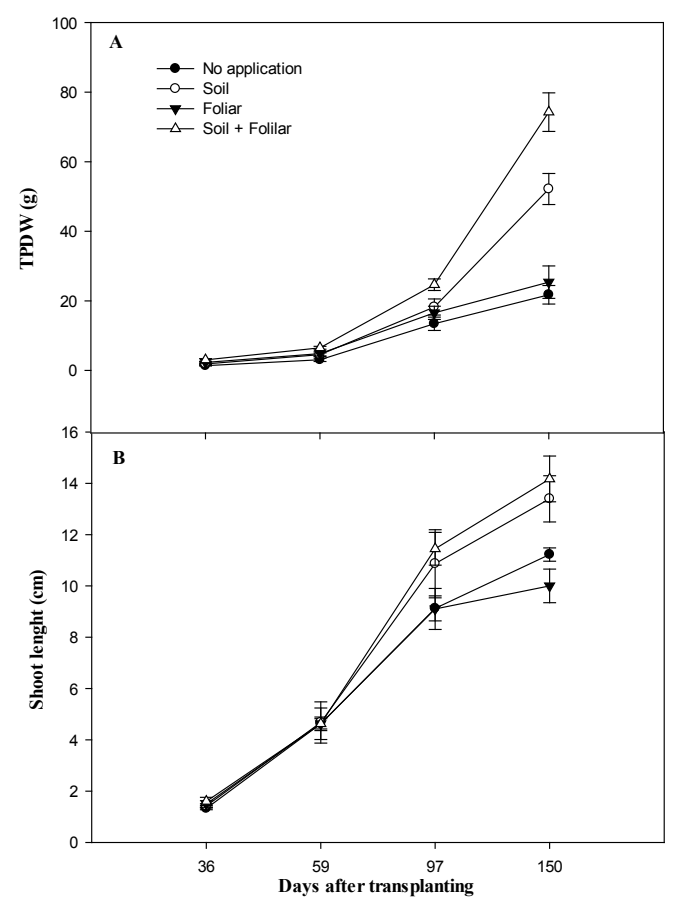

Figure 1. The effect of soil fertilizer and foliar biostimulant applications on Total Plant Dry Matter (A) and Shoot Length (SL); B) in lulo seedlings (S. quitoense var. Septentrionale). For all treatments, values are the mean of six replicates \pm standard error.

In contrast, significant differences were observed between fertilization treatments on dry matter accumulation in the leaves, root, and flower cushions, which were differences not observed in the stems. Table 1 summarizes the results of dry matter accumulation in different organs of lulo seedlings subjected to different treatments 
of fertilization at the end of the experiment. The treatment of soil fertilizer + foliar bio-stimulant showed the highest dry matter accumulation in all of the organs of the plant, followed by the soil, foliar, and control treatments, respectively. With regard to leaf area, specific leaf area, and stem diameter, similar trends to those observed in the dry weights of the organs are observed. Seedlings treated with soil fertilizer and soil fertilizer + foliar bio-stimulant applications were the ones that had better foliar and stem diameter; meanwhile, the specific leaf area was higher in plants treated with foliar bio-stimulant sprays. Significant differences were also found between fertilization treatments on dry matter distribution percentage among the different organs of lulo seedlings (Figure 2). The two treatments that received no soil fertilizer (control and only foliar bio-stimulant application) were assigned the highest amount of dry matter to root production ( $\sim 41.4 \%$, and $\sim 44.6 \%$, respectively) compared to soil treatments (soil and soil + foliar), which had $\sim 23.2 \%$ and $24.8 \%$ of their dry weight to roots, respectively.

\section{Growth rates}

Table 2 summarizes the effects of different fertilization treatments on growth rates of lulo seedlings. Significant differences between treatments from 36 DAT were observed in AGR. Plants treated with both soil + foliar application showed higher values in AGR until 97 DAT. Then, non-significant differences were obtained for AGR between treatments with both soil + foliar application and soil application at 150 DAT. However, RGR showed significant differences only at 150 DAT. The seedlings subjected to soil fertilizer and soil + foliar bio-stimulant also showed higher values in RGR. NAR also presented significant differences from 36 DAT. Plants without any kind of nutrition, either foliar or soil, showed the highest value during the experiment.

Table 1. The effect of soil fertilizer and foliar bio-stimulant applications on Dry Matter Accumulation in organs and whole plant, Leaf Area, Specific Leaf Area, and Stem Diameter of lulo seedlings (S. quintoense var. Septentrionale) at 150 days after transplanting.

\begin{tabular}{|c|c|c|c|c|c|}
\hline Treatment & Root (g) & Stem $(\mathrm{g})$ & Leaves $(\mathrm{g})$ & Floral cushions (g) & Total plant (g) \\
\hline \multicolumn{6}{|c|}{ Dry weight in plant organs } \\
\hline No application & $9.19 \mathrm{~b}^{1}$ & $5.94 \mathrm{a}$ & $6.58 \mathrm{c}$ & $0.02 \mathrm{~b}$ & $21.75 \mathrm{c}$ \\
\hline Soil & $12.24 \mathrm{ab}$ & 13.99 a & $26.45 \mathrm{~b}$ & $0.48 \mathrm{~b}$ & $52.16 \mathrm{~b}$ \\
\hline Foliar & $10.96 \mathrm{ab}$ & $5.20 \mathrm{a}$ & $9.13 \mathrm{c}$ & $0.07 \mathrm{~b}$ & $25.38 \mathrm{c}$ \\
\hline Soil + Foliar & $18.14 \mathrm{a}$ & $15.39 \mathrm{a}$ & $38.98 \mathrm{a}$ & $1.73 \mathrm{a}$ & $74.27 \mathrm{a}$ \\
\hline Significance & $* *$ & $* *$ & $* * *$ & $*$ & $* *$ \\
\hline Treatment & & Leaf area $\left(\mathrm{cm}^{2}\right)$ & Specific leaf ar & $\left.\mathrm{cm}^{2} \mathrm{~g}^{-1}\right)$ & lameter $(\mathrm{mm})$ \\
\hline \multicolumn{6}{|c|}{$\begin{array}{l}\text { Leaf area, specific leaf area and } \\
\text { stem diameter }\end{array}$} \\
\hline No application & & $823.65 b^{1}$ & 124.8 & \multicolumn{2}{|c|}{$14.80 \mathrm{c}$} \\
\hline Soil & & $2721.60 \mathrm{a}$ & 103.85 & \multicolumn{2}{|c|}{$17.87 \mathrm{ab}$} \\
\hline Foliar & & $1338.90 \mathrm{~b}$ & $207.0^{-}$ & \multicolumn{2}{|c|}{$16.30 \mathrm{bc}$} \\
\hline Soil + Foliar & & $3207.30 \mathrm{a}$ & 83.66 & \multicolumn{2}{|c|}{$18.77 \mathrm{a}$} \\
\hline Significance & & $* * *$ & $* *$ & \multicolumn{2}{|r|}{$* *$} \\
\hline
\end{tabular}

${ }^{1}$ Means within a column followed by the same letter are not significantly different by Tukey test $(\mathrm{P} \leq 0.05)$.

$* *$, *** significant at $\mathrm{P} \leq 0.01$ and 0.001 , respectively. 


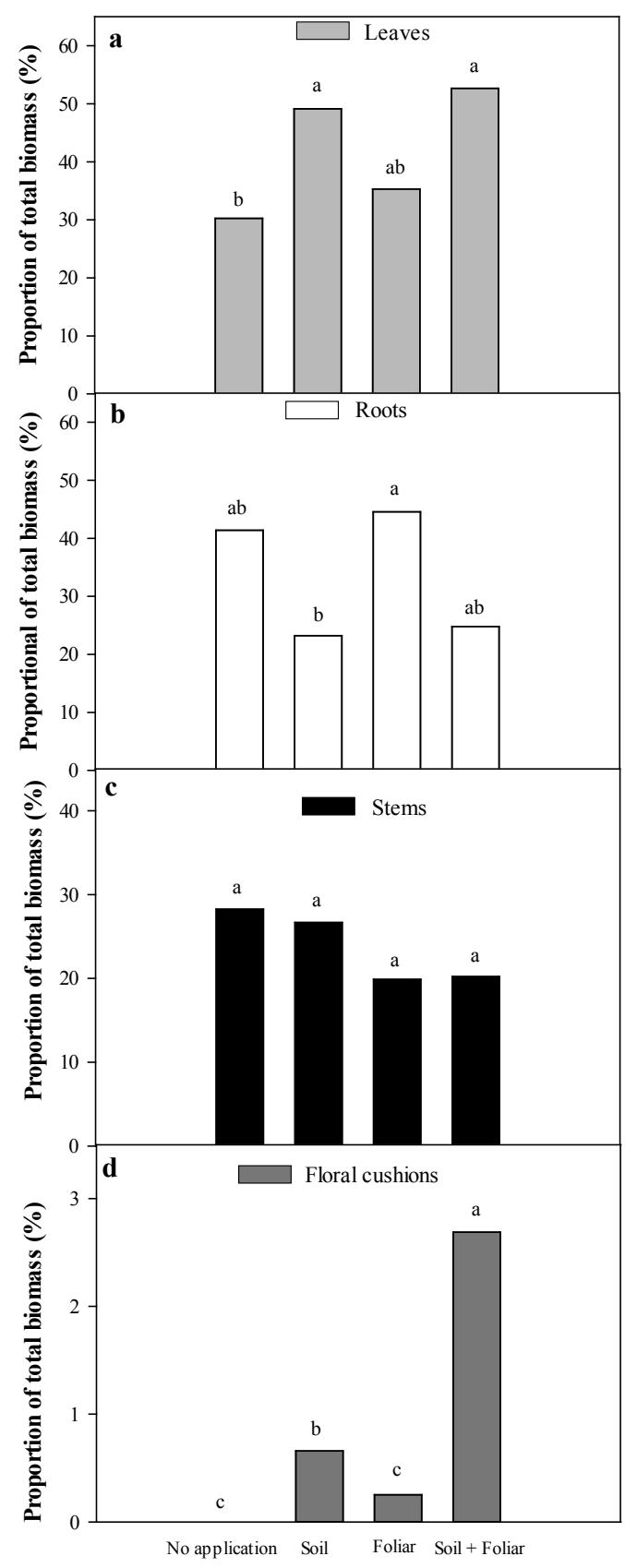

Figure 2. Effect of soil fertilizer and foliar bio-stimulant applications on the distribution of total biomass in lulo seedlings ( $S$. quitoense var. Septentrionale); (a. leaves, b. roots, c. stem, and d. floral cushions). For all treatments, values are the mean of 6 replicates. Means with different letters represent statistically significant differences according to Tukey's test $(\mathrm{P} \leq 0.05)$.
Efficiency of PSII $\left(F_{v} / F_{m}\right)$ and SPAD readings

The $\mathrm{F}_{\mathrm{v}} / \mathrm{F}_{\mathrm{m}}$ ratio was higher when plants had a better nutritional status, mainly those which were soil fertilized (Table 3). In general, all values of fluorescent chlorophyll obtained during the experiment were within the optimum range (0.7-0.8). Similarly, Table 3 shows the results of SPAD readings. In line with this trend, seedlings treated with soil fertilizer + bio-stimulant or only soil fertilizer showed the highest readings at 97 and 150 DAT, respectively.

Photosynthesis, transpiration, stomatal conductance, and WUE

Seedlings treated with soil fertilizer and soil fertilizer + foliar bio-stimulant showed the highest $\mathrm{CO}_{2}$ assimilation values. Plants with these treatments had a $\sim 75 \%$ higher photosynthetic rate compared to the control seedlings. However, the foliar bio-stimulant treatment did not show variation in the photosynthesis rate compared to unfertilized plants (Figure 3A). Likewise, a behavior similar to that described for photosynthesis was also observed for the variables stomatal conductance, transpiration, and WUE (Figure 3B, C and D).

\section{Proline contents}

An increased accumulation of this free amino acid was obtained on lulo plant leaves that received soil fertilizer, showing proline contents of $21.4 \mu \mathrm{mol}$ $\mathrm{g}^{-1} \mathrm{FW}$. Additionally, plants treated with soil and foliar methods showed a leaf concentration of 12.3 $\mu \mathrm{mol}$ proline $\mathrm{g}^{-1} \mathrm{FW}$. Finally, plants without soil fertilizer (control and only foliar application) had the lowest levels of this amino acid in the leaf, $2.3 \mu \mathrm{mol}$ proline $\mathrm{g}^{-1} \mathrm{FW}$ (Figure 4). 
Table 2. The effect of soil fertilizer and foliar bio-stimulant applications on the absolute growth rate (AGR), relative growth rate (RGR), and net assimilation rate (NAR) in lulo seedlings (S. quintoense var. Septentrionale).

\begin{tabular}{|c|c|c|c|c|}
\hline Treatment & $\begin{array}{l}36 \text { DAT } \\
\left(\mathrm{mg} \mathrm{d}^{-1}\right)\end{array}$ & $\begin{array}{l}59 \text { DAT } \\
\left(\mathrm{mg} \mathrm{d}^{-1}\right)\end{array}$ & $\begin{array}{l}97 \text { DAT } \\
\left(\mathrm{mg} \mathrm{d}^{-1}\right)\end{array}$ & $\begin{array}{c}150 \text { DAT } \\
\left(\mathrm{mg} \mathrm{d}^{-1}\right)\end{array}$ \\
\hline \multicolumn{5}{|l|}{ AGR } \\
\hline No application & $26.23 b^{1}$ & $33.94 \mathrm{c}$ & $163.61 \mathrm{c}$ & $79.40 \mathrm{~b}$ \\
\hline Soil & $30.69 \mathrm{ab}$ & $58.26 \mathrm{~b}$ & $293.48 \mathrm{bc}$ & $540.57 \mathrm{a}$ \\
\hline Foliar & $37.73 \mathrm{ab}$ & $60.55 \mathrm{~b}$ & $192.82 \mathrm{ab}$ & $64.31 \mathrm{~b}$ \\
\hline Soil + Foliar & $51.10 \mathrm{a}$ & $113.45 \mathrm{a}$ & $392.53 \mathrm{a}$ & $767.65 \mathrm{a}$ \\
\hline Significance & $* * *$ & $* * *$ & $* *$ & $* * *$ \\
\hline Treatment & $\begin{array}{c}36 \text { DAT } \\
\left(\mathrm{mg} \mathrm{g}^{-1} \mathrm{~d}^{-1}\right)\end{array}$ & $\begin{array}{c}59 \text { DAT } \\
\left(\mathrm{mg} \mathrm{g}^{-1} \mathrm{~d}^{-1}\right)\end{array}$ & $\begin{array}{c}97 \text { DAT } \\
\left(\mathrm{mg} \mathrm{g}^{-1} \mathrm{~d}^{-1}\right)\end{array}$ & $\begin{array}{c}150 \text { DAT } \\
\left(\mathrm{mg} \mathrm{g}^{-1} \mathrm{~d}^{-1}\right)\end{array}$ \\
\hline \multicolumn{5}{|l|}{ RGR } \\
\hline No application & $27.73 \mathrm{a}$ & $22.12 \mathrm{a}$ & 20.39 a & $5.67 \mathrm{~b}$ \\
\hline Soil & $27.63 \mathrm{a}$ & $26.10 \mathrm{a}$ & $19.52 \mathrm{a}$ & $12.86 \mathrm{a}$ \\
\hline Foliar & $27.45 \mathrm{a}$ & $24.17 \mathrm{a}$ & $18.86 \mathrm{a}$ & $5.61 \mathrm{~b}$ \\
\hline Soil + Foliar & $27.53 \mathrm{a}$ & $25.17 \mathrm{a}$ & $20.21 \mathrm{a}$ & $12.58 \mathrm{a}$ \\
\hline Significance & NS & NS & NS & $*$ \\
\hline Treatment & $\begin{array}{c}36 \text { DAT } \\
\left(\mu \mathrm{g} \mathrm{cm}^{-2} \mathrm{~d}^{-1}\right)\end{array}$ & $\begin{array}{c}59 \text { DAT } \\
\left(\mu \mathrm{g} \mathrm{cm}^{-2} \mathrm{~d}^{-1}\right)\end{array}$ & $\begin{array}{c}97 \text { DAT } \\
\left(\mu \mathrm{g} \mathrm{cm}^{-2} \mathrm{~d}^{-1}\right)\end{array}$ & $\begin{array}{c}150 \text { DAT } \\
\left(\mu \mathrm{g} \mathrm{cm}^{-2} \mathrm{~d}^{-1}\right)\end{array}$ \\
\hline \multicolumn{5}{|l|}{ NAR } \\
\hline No application & $195.55 \mathrm{a}$ & $89.32 \mathrm{a}$ & $27.13 \mathrm{a}$ & $8.09 \mathrm{a}$ \\
\hline Soil & $146.57 \mathrm{ab}$ & $86.33 \mathrm{a}$ & $15.11 \mathrm{~b}$ & $5.04 \mathrm{~b}$ \\
\hline Foliar & $122.84 \mathrm{~b}$ & $51.57 \mathrm{ab}$ & $15.35 \mathrm{~b}$ & $3.10 \mathrm{~b}$ \\
\hline Soil + Foliar & $94.05 \mathrm{~b}$ & $39.34 \mathrm{~b}$ & $11.34 \mathrm{~b}$ & $3.79 \mathrm{~b}$ \\
\hline Significance & $* * *$ & $*$ & $* *$ & $* *$ \\
\hline
\end{tabular}

${ }^{1}$ Means within a column followed by the same letter are not significantly different by Tukey test $(\mathrm{P} \leq 0.05)$.

NS, not significant at $\mathrm{a}=0.05{ }^{*}, * *, * *$ significant at $\mathrm{P} \leq 0.05,0.01$ and 0.001 , respectively.

Table 3. The effect of soil fertilizer and foliar bio-stimulant applications on maximum yield of PSII (F/ $\mathrm{F}_{\mathrm{m}}$ ) and Leaf Chlorophyll Content (SPAD readings) in lulo seedlings (S. quintoense var. Septentrionale).

\begin{tabular}{lccc}
\hline & & \multicolumn{2}{c}{ SPAD } \\
\cline { 3 - 4 } Treatment & $\mathrm{F}_{\mathrm{v}} / \mathrm{F}_{\mathrm{m}}$ & $97 \mathrm{dat}$ & 145 dat \\
\hline No application & $0.7107 \mathrm{~b}^{1}$ & $30.00 \mathrm{c}$ & $31.65 \mathrm{~b}$ \\
Soil & $0.7828 \mathrm{a}$ & $47.30 \mathrm{a}$ & $49.16 \mathrm{a}$ \\
Foliar & $0.7120 \mathrm{~b}$ & $36.65 \mathrm{~b}$ & $35.62 \mathrm{~b}$ \\
Soil + Foliar & $0.7712 \mathrm{a}$ & $52.17 \mathrm{a}$ & $51.78 \mathrm{a}$ \\
Significance & $* * *$ & $* *$ & $* * *$ \\
\hline
\end{tabular}

${ }^{1}$ Means within a column followed by the same letter are not significantly different by Tukey test $(\mathrm{P} \leq 0.05)$. $* *, * * *$ significant at $\mathrm{P} \leq 0.01$ and 0.001 , respectively. 

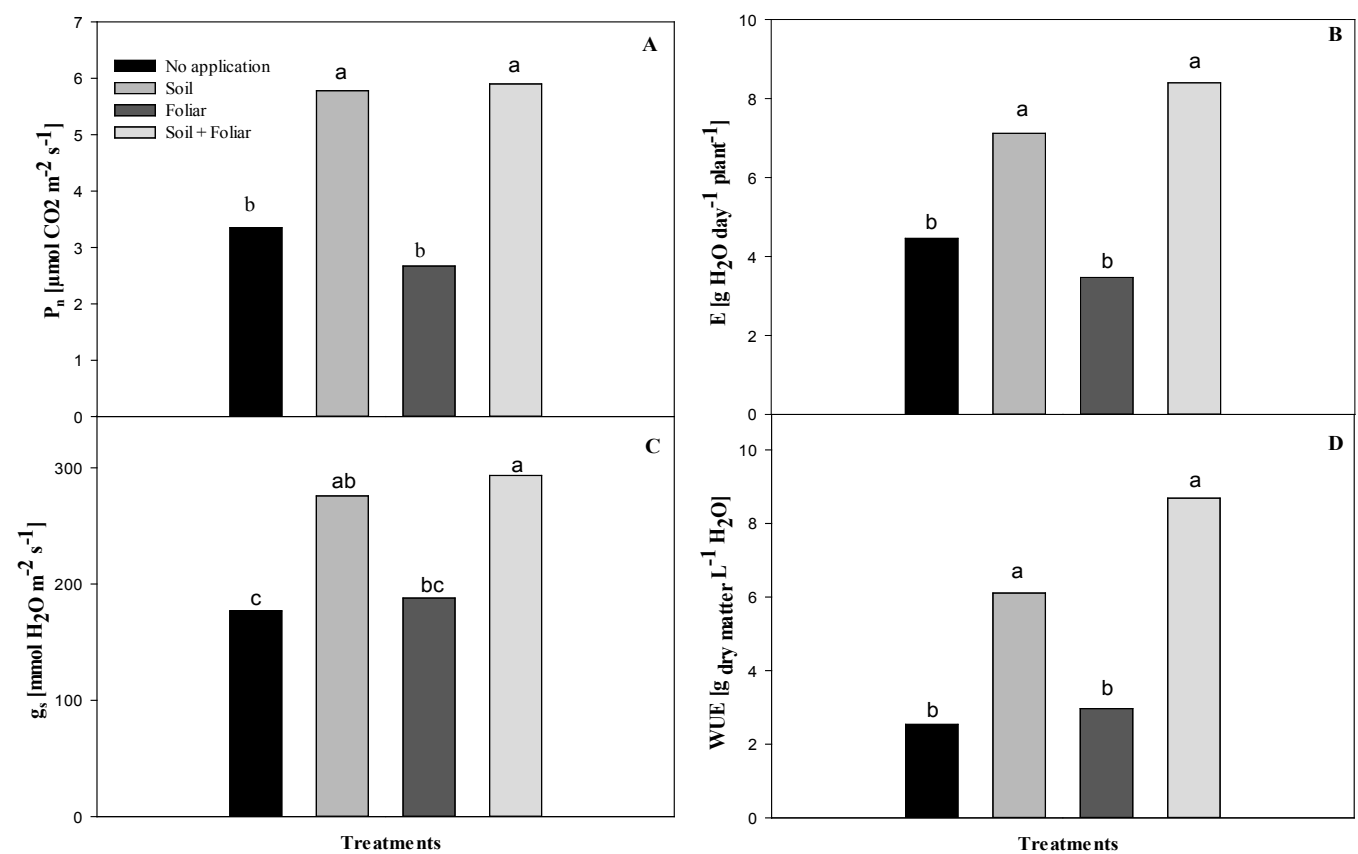

Figure 3. The effect of soil fertilizer and foliar bio-stimulant applications on A. Photosynthesis; B. Perspiration; C. stomatal conductance; D. Water Use Efficient (WUE). For all treatments, values are the mean of 6 replicates. Means with different letters represent statistically significant differences according to Tukey's test $(\mathrm{P} \leq 0.05)$.

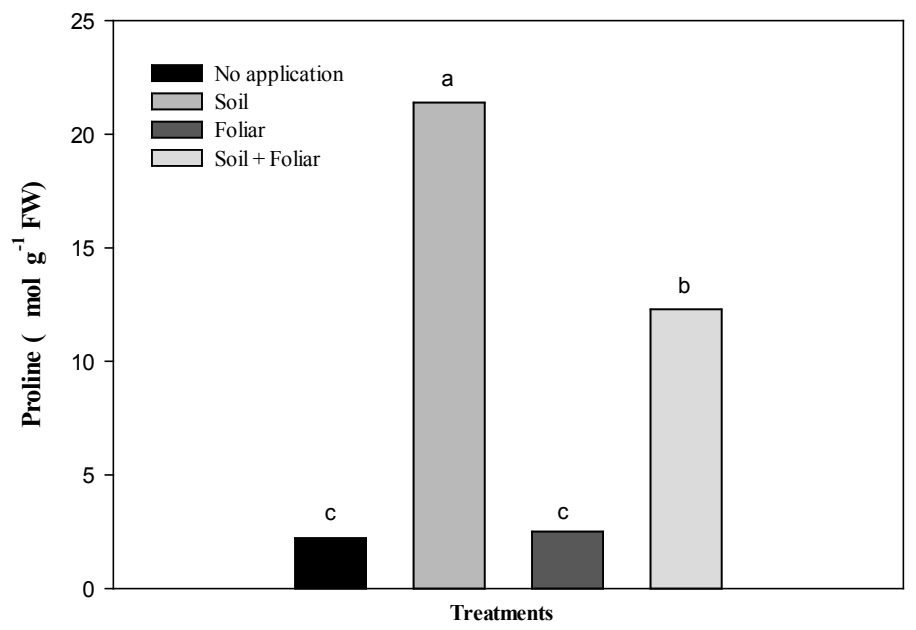

Figure 4. The effect of soil fertilizer and foliar application of a bio-stimulant on Proline content in lulo seedlings ( $S$. quitoense var. Septentrionale). For all treatments, values are the mean of 6 replicates. Means with different letters represent statistically significant differences according to Tukey's test $(\mathrm{P} \leq 0.05)$. 


\section{Discussion}

Lulo seedlings treated with soil fertilizer plus foliar bio-stimulant applications had a higher dry matter accumulation compared to the other treatments. Additionally, foliar bio-stimulant applications in plants receiving soil fertilizer favored blooming because this group of plants flowered earlier (data not shown) and had a higher accumulation and distribution of dry matter in flower cushions (Table 1 and Figure 1A and 2d). This is consistent with the results presented by Calvo et al. (2014) in which biostimulant applications also stimulated greater flower formation per plant in grapevines, and maize plants. Additionally, the activity of many of the growth regulating hormones involved in the formation of floral organs is related to an increase of amino acid synthesis by the plant. These, when applied to leaves as free amino acids, may reduce the number of days to full bloom and increase the percentage of flowering and performance parameters of the fruit (Seif El-Yazal et al., 2014). Furthermore, in our study, we found that plants subjected to soil fertilizer and soil + foliar bio-stimulant had significant increases in the height of the shoot (Figure 1B). Similar results were reported by Calvo et al. (2014), where the use of plant biostimulants enhanced the growth of plants in pear and wheat.

The Net Assimilation Rate decreased over time in all fertilization treatments with both soil and foliar bio-stimulant applications (Table 2). According to Carranza et al. (2009), this reduction is closely related to the shading that occurs on the lower leaves as an effect of the growth and creation of new leaves at the top of the plant, generating a lower interception of photosynthetically active radiation.

Moreover, poor soil nutrition caused a reduction of variables, such as the maximum efficiency of PSII $\left(\mathrm{F}_{\mathrm{v}} / \mathrm{F}_{\mathrm{m}}\right)$ and SPAD readings (Table 3). In general, plants deprived of nutrients via soil fertilization showed values in the $\mathrm{F}_{\mathrm{v}} / \mathrm{F}_{\mathrm{m}}$ ratio of approximately 0.7 , indicating that this group could have alterations in photosystem II (Gorbe and Calatayud, 2013). It should be noted that the determination of the effi- ciency of PSII is a useful tool to identify early stages of nutritional deficiencies in strawberries (Osorio et al., 2014), tomatoes, and corn (Kalaji et al., 2014), where the lowest values of $\mathrm{F}_{\mathrm{v}} / \mathrm{F}_{\mathrm{m}}$ are associated with plants with nutrient inadequacies. Similar trends were also observed in the SPAD readings where chlorophyll content was higher in the group of lulo plants with soil fertilizer. Additionally, the properties of leaf gas exchange were conditioned by the different nutrition treatments. Hence, seedlings treated with soil fertilizer and soil fertilizer + foliar bio-stimulant showed the highest values of $\mathrm{CO}_{2}$ assimilation, transpiration, stomatal conductance, and WUE (Figure 3) compared to treatments that consisted only of foliar application of bio-stimulant or control. Similar observations were reported by Neri et al. (2002) in strawberry crops where foliar applications of humic acids stimulated pigment production and water use efficiency and maintained photosynthetic rates. Additionally, Afrousheh et al. (2010) reported that nutritional deficiencies in Pistacia vera resulted in lower photosynthesis, transpiration, and stomatal conductance rates.

The highest proline concentrations were present in lulo seedlings subjected to soil and soil fertilizer + foliar bio-stimulant (Figure 4). Furthermore, proline production is related to the stress response factors in plants, including toxicity and/or nutrient deficiency (Ahmed and Hasan, 2011; Fatima et al., 2011). However, in our results, the increase of the proline content was not related to a state of stress in lulo seedlings.

In conclusion, the application of foliar bio-stimulant applications as a complement to soil fertilization is a technique that can be employed in the cultivation of lulo because it shows the highest rates of dry matter accumulation, stem length, leaf area, growth, and floral cushion number. Additionally, supplying only foliar bio-stimulant as a fertilization plan in lulo plants is not recommended because it does not meet the nutritional demands required by the plants, which is reflected in the rate of net photosynthesis, water use efficiency, flower cushion number, and growth. 


\title{
Resumen
}

\begin{abstract}
J.J. Díaz-Leguizamón, O.F. Chingaté-Cruz, A.D. Sánchez-Reinoso y H. RestrepoDíaz. 2016. Efecto de la aplicación foliar de un biostimulante de extracto de algas marinas sobre el comportamiento fisiológico de plántulas de lulo (Solanum quitoense cv. Septentrionale). Cien. Inv. Agr. 43(1):25-37. Extractos de algas marinas son usados como Fuente de nutrientes, biosetimulantes o biofertilizantes in la agricultura y horticultura con el propósito de incrementa el crecimiento y rendimiento de la planta. En este experimento, se evaluaron las aplicaciones foliar de un bioestimulante a base de un extracto de algas marinas sobre el crecimiento de la planta, propiedades de intercambio gaseoso de la hoja y producción de prolina en plántulas de lulo cultivadas bajo condiciones de invernadero. Las plantas de lulo fueron divididas en cuatro tratamientos: i) plantas con fertilización edáfica; ii) plantas tratas solamente vía foliar con el biostimulante iii) una combinación de fertilización edáfica y aplicación foliar de bioestimulante y iv) plantas control (sin ninguna aplicación de fertilizante y bioestimulante). Las plantas de lulo tratadas con fertilizante edáfico más aplicaciones foliares del bioestimulante mostraron una mayor altura de planta, peso seco total, diámetro del tallo y tasa absoluta de crecimiento. Plantas control presentaron una menor tasa fotosintética, conductancia estomática y transpiración. Asimismo, aplicaciones foliares del bioestimulante favoreció la aparición de botones florales. Los resultados obtenidos permiten concluir que el uso de un bioestimulante a base de extractos de algas marinas puede ser considerado como un complemento a la fertilización edáfica, ya que puede favorecer la acumulación de materia seca y floración.
\end{abstract}

Palabras clave: Eficiencia del PSII, fertilización edáfica, fertilización foliar, prolina, tasas de crecimiento.

\section{References}

Afrousheh, M., M. Ardalan, and H. Hokmabadi. 2010. Nutrient deficiency disorders in Pistacia vera seedling rootstock in relation to eco-physiological, biochemical characteristics and uptake pattern of nutrients. Scientia Hort. 124:141-148.

Agronet. 2015. Producción de Lulo en Colombia, 1986-2013. Estadísticas Agronet. Ministerio de Agricultura y Desarrollo Rural, Colombia. Available online at: http://www.agronet.gov.co/Paginas/ estadisticas.aspx (Website accessed: July 2015).

Ahmed, J., and M. Hassan. 2011. Evaluation of seedling proline content of wheat genotypes in relation to heat tolerance. Bangladesh J. Bot. 40:17-22.

Al-Karaki, G.N., R.B. Clark and C.Y. Sullivan. 1996. Phosphorus nutrition and water stress effects on proline accumulation in sorghum and bean. Journal of Plant Physiol. 148: 745-751.
Anjum SA, L. Wang, M. Farooq, L. Xue, and S. Ali. 2011. Fulvic acid application improves the maize performance under well-watered and drought conditions. J. Agron. Crop Sci. 197:409-417.

Ardebili, Z., A. Moghadam, N. Ardebili, and A. Pashaie. 2012. The induced physiological changes by foliar application of amino acid in Aloe vera L. Plants Omics Journal 5:279-284.

Bates, S., and R. Waldren. 1973. Rapid determination of free proline for water-stress studies. Plant Soil 39:205-207.

Brown, P., and S. Saa. 2015. Biostimulants in agriculture. Front Plant Sci. 6:671

Calvo, P., L. Nelson, and J.W. Kloepper. 2014. Agricultural uses of plant biostimulants. Plant soil 383(1-2):3-41

Carranza, C., O. Lanchero, D. Miranda, and B. Chaves. 2009. Análisis del crecimiento de lechuga (Lactuca sativa L.) 'Batavia' cultivada en 
un suelo salino de la Sabana de Bogotá. Agron. Colomb. 27:41-48.

Claussen, W., B. Brückner, A. Krumbein, and F. Lenz. 2006. Long-term response of tomato plant to changing nutrient concentration in the room environment - the role of proline as an indicator of sensory fruit quality. Plant Sci. 168:241-248.

Eraslan, F., A. Inal, A. Gunes, and M. Alpaslan. 2007. Boron toxicity alters nitrate reductase activity, proline accumulation, membrane permeability, and mineral constituents of tomato and pepper plants. JPN 30:981-994.

Fageria, N., M. Barbosa, A. Moreira, and C. Guimarães. 2009. Foliar fertilization of crop plants. JPN 32:1044-1064.

Fatima, N., N. Ahmad, and M. Anis. 2011. Enhanced in vitro regeneration and change in photosynthetic pigments, biomass and proline content in Withania somnifera L. (Dunal) induced by copper and zinc ions. PPB 49:1465-1471.

Flórez-Velasco, N., H.E. Balaguera-López and H. Restrepo-Díaz. 2015. Effects of foliar urea application on lulo (Solanum quitoense cv. Septentrionale) plants grown under different waterlogging and nitrogen conditions. Scientia Hort. 186:154-162.

Gil, A.I., and D. Miranda. 2011. Efecto de cinco sustratos sobre índices de crecimiento de plantas de papaya (Carica papaya L.) bajo invernadero. RCCH 1:142-153.

Gorbe, E., and A. Calatayud. 2012. Applications of chlorophyll fluorescence imaging technique in horticultural research: a review. Scientia Hort. 138:24-35.

Hernández-Herrera, R. M., F. Santacruz-Ruvalcaba, M.A. Ruiz-López, J. Norrie, and G. HernándezCarmona. 2014. Effect of liquid seaweed extracts on growth of tomato seedlings (Solanum lycopersicum L.). J. Appl. Phycol. 26:619-628.

Kalaji, H., A. Oukarroum, V. Alexandrov, M. Kouzmanova, M. Brestic, M. Zivcak, I.A. Samborska, M.D. Cetner, S.I. Allakhverdiev, and V. Goltsev. 2014. Identification of nutrient deficiency in maize and tomato plants by in vivo chlorophyll a fluorescence measurements. PPB 81:1-10.
Khan, W., U.P. Rayirath, S. Subramanian, M.N. Jithesh, P. Rayorath, D.M. Hodges, A.T. Critchley, J.S. Craigie, J. Norrie, and B. Prithiviraj. 2009. Seaweed extracts as biostimulants of plant growth and development. J. Plant Growth Regul. 28:386-399.

Marschner, P. 2012. Marschner's mineral nutrition of higher plant. Londres: Academic Press.Third edition. Elsevier. San Diego, USA.

Medina, C., M. Lobo, and E. Martínez. 2009. Revisión de estado del conocimiento sobre la función productiva del lulo (Solanum quintoence Lam.) en Colombia. Corpoica Cienc. Tecnol. Agropec. 10:167-179.

Mengel, K., E. A. Kirkby, H. Kosegarten, and T. Appel. 2001. Nitrogen. p. 397-434. In: Mengel, K., E. A. Kirkby, H. Kosegarten and T. Appel (eds.). Principles of plant nutrition (Fifth edition). Kluwer Academic Publishers. Springer, The Netherlands.

Neri, D., M. Lodolini, G. Savini, P. Sabbatini, G. Bonamomi, and F. Zucconi. 2002. Foliar application of humic acid on stawberry (cv. Onda). Acta Hort. 594:297-302.

Neuberg, M., D. Pavlíková, M. Pavlík, and J. Balík. 2010. The effect of different nitrogen nutrition on proline and aspargine content in plant. Plant Soil Environ. 56:305-311.

Osorio, J., M.L Osorio, P.J. Coreia, A. Varennes, and M. Pestana. 2014. Chlorophyll fluorescence imaging as a tool to understand the impact of iron deficiency and resupply on photosynthetic performance of strawberry plants. Scientia Hort. 165:148-155.

Parra-Coronado, A., G.H. Ardila-Roa, and H. Restrepo-Díaz. 2015. The physiological response of lulo plants (Solanum quitoense var. Septentrionale) to soil and foliar applications of nutrients. Int. J. Fruit Sci. 15(2):1-13.

Raviv, M., and T.J. Blom. 2001. The effect of water availability and quality on photosynthesis and productivity of soilless grown cut roses. Scientia Hort. 88:257-276.

Seif El-Yazal, M.A., and M.M. Rady. 2014. Exogenous onion extract hastens bud break, positively alters enzyme activity, hormone, amino acids and 
phenol contents, and improves fruit quality in 'Anna' apple trees. Scientia Hort. 169:154-160.

Zodape, S. T., A. Gupta, S.C. Bhandari, U.S. Rawat, D.R. Chaudhary, E. Eswaranand, and J. Chikara.
2011. Foliar application of seaweed sap as biostimulant for enhancement of yield and quality of tomato (Lycopersicon esculentum Mill.). J. Sci. Ind. Res. 70:215-219. 
